Journal of Language, Technology \& Entrepreneurship in Africa, Vol.2. No.2

\title{
COUNTER-TERRORISM IN THE GREATER HORN OF AFRICA 2004-2010: REVISITING THE SOMALIA QUESTION
}

\author{
Mumo Nzau
}

\begin{abstract}
On the $11^{\text {th }}$ of July 2010; as funs watched the FIFA World Cup Finals around the world, two separate suicide bombings rocked Kampala, Uganda leading to the deaths of 79 people and injuring many others. Al-Shabaab, a fundamentalist group in Somalia immediately claimed responsibility. These events sparked widespread debate within scholarly circles as far as the counter-terrorism agenda in the Greater Horn of Africa is concerned.
\end{abstract}

In recent years, terrorism has grown to become a vice of global magnitude. The Greater Horn of Africa has had its own share of terror attacks and terrorism-related activities since the late 1990s. The resilient anarchy in Somalia seems to have worsened the picture. Six years after the formation of the Transitional Federal Government in October 2004, Somalia is yet to have a fully operational government. This state of affairs, coupled with similar regional challenges made the Greater Horn an easy target for global crime syndicates- piracy, drugs and light weapons trafficking and most notably, international terrorism. Since late 2006, Somalia seems to be the epicentre of Islamic fundamentalism of the kind witnessed in the Middle-East in recent years. The countries in the region more often than not, are unable to tame the vice as they were plagued by internal challengesactive and/or potential conflicts amongst them.

It is against this background that this paper sought to explore the challenges facing the counter terrorism agenda in the Horn of Africa with a view to assessing the evolving terrorism threat with specific reference to Somalia and further charting the way forward on the same. The researcher arrived at the conclusion that; international terrorist activities are not a preserve of any single country. It has both short and long-term effect on almost any country. The structural features on which terrorism thrives; particularly poverty, ignorance, bad governance, disorder and insecurity all need to be addressed not only as "the Somali problem" but one that involves all state and non-state actors in the Greater Horn of Africa. This calls for concerted economic, political and security cooperation now and in future. 


\section{Introduction}

On the $11^{\text {th }}$ of July 2010; as funs watched the FIFA World Cup Finals around the world; two separate suicide bombings rocked Kampala, Uganda leading to the deaths of 79 people and injuring many others. Al-Shabab, a fundamentalist group in Somalia immediately claimed responsibility. These events sparked widespread debate within scholarly circles as far as the counter-terrorism agenda in the Greater Horn of Africa is concerned. At the centre of it is the resilient anarchy in Somalia- the Somalia Question. (Onyango-Obbo, 2010:20). In an interdependent world, terrorism is borderless. Technology and efficient communication systems along with global commerce, have indeed, changed the face of terrorism in Africa in particular, and the world in general. The modern-day style of terrorism invites a new definition of the phenomenon. Such a definition must therefore include the two faces of terrorism; it must acknowledge the terror perpetuated by states as well as the violence of transnational and national groups (Onwudiwe 2006:4).

According to Georges-Abeyei and Hass (1982:1-7); the goal of terrorism is to terrorize. Regarding their objectives, terrorist acts are atrocious and create confusion among the general public (Colliers J. 2003: 91-103). The Greater Horn of Africa has had its share of the atrocities and implications of global terror. The region was shocked by the dual bombings of American embassies in Nairobi, Kenya, and Dar es Salaam Tanzania that claimed over 250 lives in 1998. It also witnessed the bombings of the "USS Cole in Aden, Yemen in 2000, and the bombing of the Israeli owned Paradise Hotel in Malindi, Kenya in 2002. Terrorism experts have noted that the events in Africa epitomise the view that attacks on the United States and other targets did not occur in isolation; they all demonstrate the global nature of terrorism (White 2006).

The community of world states has over this period (1998 to present) continued to take active and decisive measures to combat the vice in what has evolved to become 'global war on terror'. But as time went by, international terrorist movements equally made efforts in order to counter and/or avoid any legal and military action directed towards them (Knonenwetter 2004:vi-ix). This state of affairs therefore continues to make counter terrorism a complex and indeed, a very dynamic realm. What is certain about it is that; it can only materialize through joint action and purpose-driven cooperation among countries.

Despite the absence of a significant terrorist attack in the Greater Horn region over the past few years, terrorist movements remained active in the region. At the same time, Somalia continues to be an epicentre of anarchy right in the heart of the region. The Transitional Federal Government (TFG), which was formed in Nairobi, Kenya (following the IGAD-driven Somalia National Reconciliation Conference) in October 2004, was not able to establish its authority over the war torn country (Albert Walkers 2005:10-16). In mid 2006, insurgents backed by the Islamic Courts Union overpowered forces loyal to the TFG and captured Mogadishu, Somalia's capital. (The East African 2006: 19). It took the intervention of Ethiopian forces to stem the growing popularity of the Union of Islamic Courts (ICU) and the eminent overthrow of the TFG government in December 2006. But the Ethiopian intervention could only cure the symptoms and not the disease; 
the ICU had already "done the harm" (The Daily Nation: 2007:14). It is against this background that the United States of America stepped up its counter-terrorism operations in the Eastern Africa region, particularly the Horn. Indeed, twice in January 2007, a U.S warplane launched offensive attacks on suspected Al Qaeda bases in Somalia (Daily Nation 2007:1).

From then on, Somalia continued to witness a series of suicide bombings- reminiscent of the Iraq situation -with the latest series of such attacks targeting the Somali president, Abdullahi Ahmed Yusuf, his then Prime Minister Ali Mohammed Ghedi, African Union Peacekeepers and any other form of resistance to the ICU course, especially Ethiopian forces in Somalia, whom they deemed to be American backed.

At the political and military-security/strategic levels; these developments clearly sent serous signals to the defence and national security formations in the Greater Horn of Africa and beyond. Against this background, this article re-examines the evolving terrorist threat in the region with specific reference to Somalia. This is in view of better informing the counter-terrorism agenda in the Greater Horn of Africa region.

\section{The Evolving Terrorist Threat in the Greater Horn of Africa}

The region in focus here comprises of the following countries: Somalia, Ethiopia, Eritrea, Sudan, Kenya, Uganda, Tanzania and Djibouti. It is noteworthy that though Somalia seems to be at the epicentre of the terrorism debate, it is not the monopoly of terrorist activity. The term "terrorism" has no precise or widely accepted definition. The problem of defining terrorism is compounded by the fact that terrorism has often been applied to a variety of acts of violence, which are not strictly terrorism by definition. Some definitions focus on the terrorist organization's mode of operation while others emphasize the motivations and characteristics of terrorism. Thus, a universally acceptable definition of terrorism is difficult to have, for one man's terrorist will always be another's freedom fighter. The United Nations describes terrorism as criminal acts intended or calculated to provoke a state of terror in the general public, a group of persons or particular persons. Such acts may be invoked by political, philosophical, ideological, racial, ethnic or religious considerations (UN General Assembly Resolution 49/60, December 1995).

Nonetheless, certain events in the Eastern Africa region in recent years were nothing short of terrorist atrocities. The war in Western Darfur, attacks on civilians in Northern Uganda, the Mungiki and Sabaoti Land Defence Force (SLDF), the Turbi Massacre and the January 2008 Post-Election Violence in Kenya did exhibit what would pass to be terrorist activity. Three major factors can be identified in an account of the growing terrorist activity in these countries. These factors include:

\section{Proximity to and historic linkages with terrorist hubs and other precipitant processes}

These historical linkages are two fold: Those that stem from the people's cultural history on one hand, and those associated with their contemporary socio-political experience. On the latter for instance, it can be claimed that terrorism in the region originates from revolutionary pressures at home, regional battles, economic conflicts and regime tyranny. This is largely true particularly with Uganda, Sudan, Ethiopia and Somalia where several 
aspects of conflict have led to armed insurgency and outbreaks of terrorism at lest of the domestic nature (Martha Glenshaw: 1994). In April 26 $6^{\text {th }}$ 2002, for example, guerrillas from the Lord's Resistance Army (LRA) swept down on a funeral in the Southern Sudan. Sixty mourners are gunned down after reportedly being forced to cut up and eat the corpse that was being buried (Michael Kronenwetter: 2004: 211).

On the other hand, cultural factors and proximity to terrorist hubs around the globe (especially the Middle East) offer even more vivid explanations to the growing terrorism threat in the Greater Horn of Africa region (West D.L.: 2005). The problem not being Islam as such; the heavy presence of Muslim populations in these countries provides a safe haven for extremists to hide. The percentages of Muslim population in the region are as follows: Djibouti (94\%), Eritrea (50\%), Ethiopia (50\%), Somalia (100\%), Sudan (70\%), Tanzania (35\%), Uganda (16\%) and Kenya (10\%). In this light, it is noteworthy that at least three suspects of the failed London bombings in 2005 were born in East Africa (Tom Downey’s: 2006:18-23).

Similarly, proximity of the Comoros Island and Yemen is a factor to reckon with. Yemen is separated from Djibouti and the rest of the Greater Horn by a relatively brief sea front to the East of the Gulf of Aden. Most wanted Al-Qaeda militants have used Yemen either as a training base or as a transit point before launching attacks in the Greater Horn region (Tom Downey's: 2006:18-23).

\section{Weak Security Infrastructure Characterized by Porous and un-policed Borders}

A couple of governments in the Greater Horn of Africa tend to be preoccupied with their internal political survival to the effect that terrorist operatives easily penetrate the countries involved. Faced with various belligerent movements from within -and coupled with poor economic performance and poor weak technological infrastructure- such regimes are weakened and thus make it easy for international terrorist organizations to develop linkages with domestic cells and/or criminal groups and further exploit traditional networks of money transfer and remittances to further their goals. In the process, they manage to melt into needy populations in refugee camps and among asylum seekers. This way, depressed economies and unstable states provide hideouts for terrorists to thrive in. When countries have poor security infrastructure, it simply implies that international terrorist groups will easily penetrate their territories unchecked (Schwartz S.: 2003). In January 2007 alone for instance, Kenya's Anti-Terrorist Police Unit (ATPU) rounded up 11 suspected terrorists as they attempted to enter the country from Somalia (Daily Nation: 2007:5).

\section{Resilient Anarchy in Somalia and the Regional Dynamics of Terrorism}

In the past few years, the International Community has renewed its interest in Somalia because of the threat of terrorism from extremist Islamic groups; Al-Qaeda itself or others using the environment of the Somali collapsed state as a safe haven to operate with impunity. Such terrorism has been a threat in Somalia for over a decade and remains so today. Nevertheless, the continued lack of international political engagement has permitted an already unstable situation to deteriorate thereby creating potential for more 
violence and lawlessness of the sort that can offer terrorists greater opportunities (International Crisis Group African Report No. 45:1994).

\section{Overtones of State Sponsored Terrorism in the Greater Horn}

Regional politics and security concerns continue to play themselves out -often violentlywithin Somalia. Regional tensions have often been essentially complicated by political cleavages inside the country and the tendency of regional powers to use local militias to advance their goals. While it is tempting to portray some of these tensions as "a clash of civilizations” between a highland, Christian Ethiopian leadership and a lowland, Muslim bloc that combines Somalis, Arabs and other ethnic groups, reality is more complex. In essence, Somalia's relationship with Ethiopia is very uneven with some areas reviling their neighbour and others looking to it for support. The roles of the Arab states may be diverse, while those of Djibouti, Kenya, and Eritrea do not fit easily into an EthiopianArab dispute. The ill-defined but burgeoning role of Islamic non-state actors has increasingly become important (International Crisis Group Africa Report: 2004:8).

Whenever Ethiopia sneezes in the Greater Horn of Africa the region catches a cold. Its location in the Horn is strategic. Yet, it is land-locked and its long and complicated border has been a flashpoint for conflict on many occasions (Muthama: 2007:19) In late 2006, Ethiopia's Prime Minister Meles Zinawi maintained that Ethiopia was “technically” at war with Somalia's Islamists because they had declared Jihad on his nation. In mid-December 2006, Ethiopian troops were already inside Somalia waging war against the Somalia Islamic Courts Union. After a week of artillery and mortar duels between the two sides, the situation had spiralled into an open war. By the end of December, forces loyal to the TFG had gained control of towns held by the ICU, thanks to the Ethiopian intervention (Daily Nation: 2006:16). To the Islamic Courts Union leaders, this was a conflict against a Christian-led Ethiopia; a holy war against “Crusaders” while Ethiopia and her allies portrayed it as a war against Al-Qaeda linked terrorists.

The derailed Ethiopia-Eritrea peace process is a key factor fuelling the war situation inside Somalia. The two countries have taken sides in the conflict with Ethiopia backing the TFG on one hand and Eritrea supporting the ICU. In the real sense, both countries are using the war as a proxy to settle their own political scores; yet this in itself can pass to be state sponsored terrorism especially on the part of Eritrea and Ethiopia. According to the former US Assistant Secretary for African Affairs Jendayi Frazer "The Council of Islamic Courts is now controlled by East Africa Al-Qaeda cell individuals. The top layer of the Courts is extremist to the core and they are in control; and that is the problem" (Terrence Lyons: 2006:7). Addis Ababa on its part worries that a hostile government in Mogadishu would strongly support the Oromo National Liberation Front (ONLF) and the United Western Somali Liberation Front (UWSLF) and revive earlier goals of encouraging the Somali inhabited areas of Ethiopia to join it. 
Although a member of the Arab League, Djibouti's policy is the product of sometimescontradictory elements. Ethnic and historical ties ${ }^{1}$ in Ethiopia place Djibouti under a special obligation to show leadership on Somali affairs. Another major consideration for Djibouti is its symbiotic commercial relationship with Ethiopia. Economic dependence on transit trade obliges it to maintain a working relationship with its southern neighbour. On the other hand, Ethiopia's almost exclusive dependence on Djibouti's port since closure of the Eritrean port, Assab, places it under a similar obligation (International Crisis Group, Africa Report No. 45, 2004:7).

When the Islamic Courts Union took over in mid 2006, Djibouti did not take a clear-cut position on what side to support. Nonetheless, a report released by the US Department of State in late 2006 claimed that Djibouti not only acknowledged having provided the TFG with 3000 military uniforms but also formally received a senior Islamic Courts delegation in September 2006. It must be remembered too that Djibouti is predominantly a Muslim state. In this light, it has tended to treat the Somali problem as a Muslim and/or Arab affair. It is for this reason that Djibouti strongly supported the Arab League mediation talks held in Khartoum in 2007, with a view to finding a peaceful solution to the battle for political control in Somalia, between the TFG and the ICU.

In early 2009, the mandate of the Transitional Federal Government (TFG) ended and President Abdullahi Ahmed Yusuf left office. This saw the rise to power of Sheikh Sharrif Ahmed as President with Omar Abdirashid Ali Sharmarke as Prime Minister. Although Sheikh Sharrif was himself a former prominent member of the Union of Islamic Courts, his rise to power seemed not to auger well with the Islamist groups fighting for control of Modagishu, Somalia's capital. The US among many other countries including the European Union, IGAD and the African Union seemed to approve of President Sharif's leadership. The US particularly regards him to be a moderate who can quell extremism and restore order in the war torn country. Yet despite these developments, typical terror attacks continued to take place inside Somalia.

The fall of the Union of Islamic Courts and the Rise of Al-Shabaab in Somalia: A Critical Analysis of the Terrorist Connection

Following the formation of the TFG in Nairobi in late 2004, President Abdullahi Yusuf Ahmed and his allies, under pressure from Kenya the Intergovernmental Authority on Development (IGAD) states to relocate to Somalia set up a provisional capital in Jowhar on the grounds that Mogadishu was insecure. Two assassination attempts on Prime Minister Ali Mohammed Ghedi while visiting the old capital city did at least confirm the TFG's fears. Nonetheless, key figures in Yusuf's government led by Hassan Adan (the speaker of Parliament) preferred to have Mogadishu as the capital (The East African, November 22-28, 2004:4). They finally settled on Baidoa, a neutral town 250 kilometers northwest of Mogadishu. All this while, Mogadishu and its environs was in the hands of warlords who had formed strongholds around the ruined city following more than a decade of anarchy. Meanwhile, another force sprung to power, the ICU (The Islamic

\footnotetext{
${ }^{1}$ Djibouti's population is roughly half Somali and its head of State, President Ismail Omar Guelle, is an ethnic Somali born.
} 
Courts Union) in June 2006. The ICU captured Mogadishu from the warlords who had already formed an alliance -the Alliance for Restoration of Peace and Counter-Terrorism (ARPCT).

The rise of the ICU marked the emergence of militant Islamism as a major ideology that cut across traditional social divisions and challenged traditional modes of dispute resolution by ascending to some degree above the clan structure. The Islamic Courts began a decade ago as a local clan-based mechanism for dealing with chronic lawlessness in Mogadishu (Crisis Group Africa Report No. 116, 2006:16-17). It was valued by locals and business interests as one of the few sources of governance in the south that brought a degree of peace and security unknown to the troubled country. For a long time under its reign, Mogadishu was reunited, militia checkpoints were torn down, weapons were removed from the streets and the international port and airport reopened for business. By December 2006, the courts had expanded from their Mogadishu base to control most of southern Somalia, before they were rooted out by Ethiopian and TFG forces.

The Muslim Brotherhood -a worldwide Islamic movement that started in 1828 and which gave birth to several religious and political organizations in the Middle East is said to have been introduced to Somalia in mid $19^{\text {th }}$ century by local scholars returning from Egypt and most Islamic Courts members in Somalia subscribe to it (Meir 2003). But within this setting there are several ideological extremes: on one hand are the "Salafiyya" a largely apolitical outfit that, however, promotes literal interpretation of the Koran; while on the other hand are the more radical ones who prescribe to "Salafi Jihadism" a brand of Wahabism- One such group is the Al-Ittihaad Al-Islaamia (AIAI).

In the mid 1990s, this group waged a guerrilla assault against Ethiopia, ostensibly to unite all Somali-speaking people to their ancestors -Somali irredentism (John Mbaria, 2007:14). The most prominent member of this group within the Union of Islamic Courts (ICU) is the famous Sheikh Hassan Dahir Aweys. Another such leader is Adan Hashi Aryo who is a militia commander of one of the courts. He is considered an extremist Muslim and was trained in Afghanistan. He came to the fore following the recent attacks that involved the desecration of Italian cemeteries in Mogadishu and was blamed for killing five western aid workers and BBC journalist Kate Peyton in 2005. He is largely viewed as a newcomer on the Somali scene, being mentored by Aweys. Finally, there is Sheikh Sharif Ahmed, who is the Executive Head of the UIC. Upon the ICU's control of Mogadishu in mid 2006, Sheikh Sharif's assurance to the International community that the ICU is against terrorism reinforced his moderate position. He maintained that the ICU takeover was a popular revolution that sought to enable the Somali people choose their country's destiny and a response to anarchy and plunder by the warlords (Cedric Bernes and Harun Hassan 2007:12-14). The other key ICU leader is Sheikh Hassan Hersi "AlTurki” who is formally a leader of Al-Itihaad al-Islamiya (AIAI). Since 2004, Hassan AlTurki was designated under US presidential Executive Order 132224 for terrorist financing. He is controversial in that he is a former warlord who occupied the lower Shabelle in 2003 but later allied himself the Islamic Courts (The Economist, January 4, 2003). 
Since its formation in late 2004, the Transitional Federal Government was unable to establish control over Somalia. Right from the beginning, it was faced by opposition from two fronts: an associated group of militia led by warlords on one hand and several groups of Muslim leaders who held Islamist and/or antiwestern views as far as the future of the country was concerned. Many incidences continued to send the signal that all was not well in Somalia. In February 2005, a bomb blast killed two people and wounded six others in a visit by African Union (AU) experts who had been on a fact-finding exercise aimed at preparing Somalia for an AU peacekeeping mission (The Standard, February 18, 2005:19). Earlier in November 2004, President Abdullahi Ahmed Yusuf was attacked at his Nairobi residence; an incident that raised fears that the warring factions in the lawless state were extending their rivalry in Kenya (The East African, 22-28 November, 2004:1).

In May 2006, the leader of a self-proclaimed counter-terrorism alliance warned that the Somali government had been infiltrated by extremists who were Al-Qaeda sympathisers. Mohammed Omar Habre alias Mohammed Dhere was the leader of the Alliance for the Restoration of Peace and Counter-Terrorism. On its part, the Union of Islamic Courts (ICU) accused the warlords of being the 'real terrorists' who "deserved to be tried for war crimes... but instead were accorded safe haven," and enjoyed US backing (Daily Nation May 21, 2006).

Since the December 2006 triumph of the TFG (backed by Ethiopian forces) over the ICU, a new wave of typical terror attacks have characterized the ICU course. In late 2006, two suicide bombings were reported in Baidoa where the government was stationed at the time. The insurgents adapted Middle East style suicide bombings. At least one person blew himself on April 19, 2007 near an Ethiopian military compound. At least two Ethiopian vehicles entering the compound were destroyed to small pieces. On April 24, a suicide bomber attacked an Ethiopian forces compound in Afgoye town, 30km south of Mogadishu. There were no immediate casualty reports. On April 25, 11 people were killed in a suicide attack on a major hotel around KM4 roundabout, south of Mogadishu where the Somali government officials are based. On June 3, a truck bomb exploded outside the residence of the Somali interim Prime Minister Ali Mohamed Ghedi. At least six people were killed and 10 injured - most of them bodyguards. A militant Islamic group claimed responsibility for suicide bombings; vowing to continue attacks until “occupiers” left Somalia (The East African June 12-18, 2006: 19).

The group who called themselves the Mujahideen Youth Movement said in an Internet statement “...our brave brother Abdul-Aziz Mohammad Senter carried out a heroic martyrdom operation at the resident of the apostate Prime Minister. Your brethren at the Mujahideen youth Movement are pressing on with their holy fight against all occupiers and apostates." (The Daily Nation, June 5 2007:18). At the same time, Ethiopian forces managed to thwart yet another suicide bomb attack when they shot dead a would-be suicide bomber; blowing up his vehicle which was filled up with explosives as it raced towards their command headquarters in the Somali capital Mogadishu. Members of the ousted Islamic Courts openly declared and vowed to wage an "Iraq-style" insurgency. In this direction, they tossed grenades into crowds and civilian targets and were behind the 
killing of a Somali journalist Mahad Ahmed Eluno who was perceived to be "western" oriented. In March 2008, the United States launched another air raid over the town of Dobley claiming that the attack was against a well known Al Qaeda terrorist. The strange thing was that following the attacks, hundreds of Somalis staged protests saying they did not approve any American activity because the Americans were against their religion and culture (Daily Nation March, $5^{\text {th }}$ 2008).

According to Salim Lone, "Islamists are now fully part of the mainstream in all Muslim societies. Their parties have established a powerful presence in a growing number of countries, including Sudan, Iran, Palestine, Pakistan, Somalia and Egypt.” Salim Lone (2007:11). The message being sent here by Salim Lone; and with the current conduct and disposition of insurgency on the part of ICU components inside Somalia; coupled with its regional ramifications, connections, and implications -one thing is for sure; circles of international fundamentalist terror groups have finally gained influence and operationalization in the Greater Horn of Africa region. True enough, on September $17^{\text {th }}$ 2009, Al-Shabaab insurgents detonated two suicide bombs at the African Union peace keeps' headquarters in Mogadishu, killing nine on the spot. The death toll following this attack later rose to 21. The insurgents were avenging the killing of the Kenyan born Saleh Ali Saleh Nabhan by US Special Forces a week earlier. Washington had reported Saleh was on the Federal Bureau of Investigation's list of Most Wanted due to his alleged Master Plan role in the 2002 bombing of an Israeli-owned hotel in Mombasa.

Meanwhile, the United States claimed that Ahmed Al Fazul, a most wanted terror suspect may have been killed in the attack. Fazul is believed to be a key mastermind for the 1998 terrorist attacks on US embassies in Nairobi and Dar es Salaam and subsequent ones in 2002 in Mombasa However, Kenyan security agencies believe that Fazul is alive and is part of Al-Shabaab's top command. Fazul remains the most wanted man on the Kenya Police website. The Rewards For Justice Program of the United States Department of State is offering a reward of up to 5million Dollars for information leading directly to the apprehension or conviction of Fazul (Daily Nation, $9^{\text {th }}$ March 2010). During 2009 and early 2010, suicide bombings were rife in and around Mogadishu, Somalia's war-battered capital. Since June 2009, five Somali ministers have been killed by suicide bombers. These attacks show that Al Shabaab is a formidable destabilizing factor to the present government (Hassan and Malkadir, August 2010).

Yet while Washington maintains that Al-Shabaab is al Qaeda's proxy in Somalia, the leader of the Union of Islamic Courts Sheikh Dahir Haweys called for more attacks until all foreigners left Somalia. It seemed that Al-Shabaab activity was confined to Somalia in its move to oust the Government of Sheikh Sharrif Ahmed through conventional or unconventional warfare- whichever met their goals best. It need not have been surprising when Al-Shabaab claimed responsibility for the Kampala $11^{\text {th }}$ July terror attacks. This now meant that international terrorism in the region was alive and fully operational; with its epicentre being Somalia. But the great question here is: Why Uganda? It appeared that Uganda's active involvement in the African Union Military Operation in Somalia (AMISOM) was the main reason for the terror onslaught on Kampala. But why should Kampala suffer for its role in a peacekeeping force that is supposedly "African?” Perhaps 
the authenticity and clout of the entire operation is wanting. Indeed, the resilience of anarchy in Somalia was at the centre of debate during the African Union (AU) Summit held in Kampala on $5^{\text {th }}-8^{\text {th }}$ of July 2010. Although the African Heads of State strongly condemned that Kampala terror attacks, they seemed unable to provide a final and lasting solution to the ‘Somalia Question' (Voice of America, July 2010).

\section{Future Counter-terrorism Efforts in the Greater Horn of Africa: Lessons for IGAD and $A U$}

There are two basic approaches in any counter terrorism strategy: one that seeks to abate and/or ameliorate situations of structural conflict thereby acting to pacify populations and divert their attention from terrorist ideology and activity; and the one (and most easily preferred) that involves coercive methods -military action and legal punitive measures. Yet the threat of terrorism in the region and other parts of the world is ever growing, ever manifest. Perhaps it is crucial to examine key actors in the region and the issues involved as far as counter terrorism is concerned.

The Intergovernmental Authority of Development (IGAD) was instrumental in the peacemaking processes that saw the end of civil wars in Sudan and Somalia. The Nairobi Somalia National Reconciliation Conference (SNRC) was under the IGAD mandate. Naturally therefore, IGAD (at least in principle) has tended to support the TFG, which it helped form. In June 2006 IGAD regional ministers ratified a Kenya-led travel ban on Somali warlords. The ministers who met under the chairmanship of Kenya's Foreign Affairs Minister Raphael Tuju agreed to work with the International Community to isolate the warlords by freezing their accounts throughout the world. The East African (August 7-13, 2006:8).

Nonetheless, the ministers extended amnesty to warlords who might have previously been involved in atrocities against the Somali people but were ready to surrender and work with the TFG. In the same light, in March 2006, IGAD mandated Ethiopia and Uganda to deploy a peacekeeping force in Somalia. It was further resolved that the UN arms embargo remains but with exceptions to allow the TFG to maintain law and order. Also IGAD cautioned the international community against offering any form of support to any parts in Somalia without consulting it and the TFG. Finally, they called upon the USA to stop any unilateral and parallel initiatives on Somalia.

Yet in August 2006, IGAD was confronted with a number of issues that put her in a rather compromised situation. During an extraordinary meeting of IGAD Foreign Affairs Ministers in Nairobi, IGAD warned particularly Ethiopia and Eritrea from taking unilateral actions that undermine the powerless but internationally recognized TFG. The East African (August 7-13, 2006:8).In the same vain, it seemed as though IGAD was not able to meet these desired objectives. The US had already taken sides and was supporting warlord factions against Islamic militias. It was claimed that these warlord operations were run from a CIA station in Nairobi. The Daily Nation (January 12, 2007:11). Other IGAD member states seemed to be divided over who to support and who not to protect in Somalia. 
Peacekeeping for Somalia was meant to support the TFG (now defunct) and stop any resurgence into full-scale war. On March $1^{\text {st }}$ 2007, President Museveni of Uganda flagged off a 1600-strong peacekeeping contingent under the AU mandate. The Ugandans are the only ones in the country and the Ethiopian forces who are "simply there to support the TFG” (The East African, June 11-17, 2007:6). Despite spirited efforts by the African Union (AU) and the Intergovernmental Authority on Development (IGAD) through its then chair, Kenya's President Mwai Kibaki, enthusiasm for the initiative has been lukewarm. Mr. Kibaki, whose term as IGAD Chair was extended for one year in 2007, sent as many as eight cabinet ministers on a major diplomatic offensive to drum up support for the Somali peacekeeping efforts. The Kenyan emissaries were sent to Rwanda, Tanzania, Mozambique, Angola, Zambia, Tunisia and Algeria. Out of these, only Uganda has responded with an offer of troops ${ }^{2}$. Most recently, Uganda's Security Minister Amama Mbabazi revealed that Kampala had decided to establish direct contact with militia and insurgents not only to pre-empt further attacks on Ugandan troops, but to re-emphasize the country's role as a neutral player in the conflicts.

From the foregoing, there can be identified three major areas that should better inform the counterterrorism agenda in the Greater Horn of Africa region. First; is there a well coordinated counter terrorism strategy so far? It goes without saying that terrorism and counter-terrorism needs a re-definition as far as the Greater Horn of Africa region is concerned. Although the EAC countries seem to be well connected and organized in their counter-terrorism efforts; a good number of their IGAD counterparts are not reading from the same script. From this discussion, it is clear that to countries such as Ethiopia, Eritrea, Sudan and Djibouti, there is no consensus on who the terrorist are, especially with respect to the political divide inside Somalia. In the larger picture, there wasn't agreement on whether to go the non-coercive (mediation, negotiation, reconciliation) or coercive way. The TFG in Somalia was unable to operate well because the IGAD countries, which were instrumental in its formation, have not worked together to support it. As at now, only Uganda has deployed troops in the AU mission in Somalia. The TFG has had a raw deal from fellow members as far as IGAD is concerned. On the military action, there has not been a clear and well-coordinated approach. From the onset Ethiopia's intervention in Somalia was unprocedural since it lacked either IGAD or AU backing; the result of which is a stalemate situation of the Iraq kind in the past several months.

Second; what has been done to deal with Structural Conflict situations in the Greater Horn Region? Certain underlying circumstances political, economic and socio-cultural breed conflict situations. In this light, poverty, disaffection and hopelessness do not directly cause terrorism, but provide an environment in which terrorists can be recruited and terrorism can thrive. This is what is happening in Somalia and parts of Sudan, Ethiopia and Uganda. The Somalia case is particularly worrying since there seems not to be a clear "way forward" on how these problems can be addressed. The problems facing Somalia are immense. For instance, a good percentage of young people in Somalia were born and brought up after 1991 (West 2005). They don't know any other way of life but war. Today, the future of conflict management efforts in the Horn of Africa remains

${ }^{2}$ (From interviews with officials at Kenya's Ministry of Foreign Affairs) 
uncertain in almost all cases with the exception of Southern Sudan ${ }^{3}$. Darfur, Northern Uganda, Eastern Ethiopia, Eritrea-Ethiopia tensions among others all remain as moribund issues that could explode to affect the region rather adversely.

Thirdly; what has been achieved through Intelligence Cooperation? The modern digital environment has made terrorism and other transnational crimes vastly easier to coordinate on a worldwide scale. It has also exacerbated a very serious challenge: governments attempting to stop terrorists-particularly democracies - are expected to do so without undermining the laws, representative principles and informal confidences upon which a culture of democracy depends on (Jennifer Sims (2007:39-56).

What makes terrorists particularly difficult intelligence targets for traditional systems is that they organize networks, insinuate themselves into open societies, and kill suddenly. Whereas traditional collectors were designed to penetrate governments located in state capitals or military deployments located in discrete battlefields, terrorists specialize in operating in small numbers and under the skins of their adversaries that is, wherever they can do the most harm. They fashion themselves to look like their targets and burrow into society to lie in wait. In this sense, they occupy the moral space as assassins, but without the assassin's traditional limits on targeting. Deceit is part of terrorists' stock-in-trade and innocents are their intentional victims. Their offensive operations are also crucial to their defense; by instilling fear and panic, terrorists create sufficient confusion to enable their swift escape. As far as intelligence for counter-terrorism is concerned the Greater Horn of Africa countries seem not to have realized that to fight a network of Al-Qaeda cells in the region; a network of intelligence is essential. On several occasions since 2004, intelligence and defense chiefs from the region met in Khartoum and Nairobi towards this aim. However, there is need to implement the plans in a better way.

\section{Conclusion and the Way Forward}

A new resilient form of fundamentalism seems to have caught countries of the Greater Horn of Africa unawares. Fully operational terror cells are indeed at work inside Somalia, Sudan, Ethiopia, Kenya and most recently, Uganda. The IGAD group of countries is squarely to blame since their approach to the Somali problem in particular was aberrantly inconsistent and disorganized especially since the formation of the TFG in late 2005. For this reason state sponsored terrorism cannot be overruled especially on the part of countries (in the region and beyond) using Somalia as a proxy for settling old scores. For there reasons, there is need to re-engineer the current counter terrorism strategy in the region. It is recommended that:

All the countries in the Greater Horn of Africa must congregate on this matter and work towards a common anti-terrorism policy. If there is one, then it needs to be well coordinated and operational.

Governments in the region should work towards strengthening governance and governmental capabilities, building and maintaining infrastructure, creating jobs,

\footnotetext{
${ }^{3}$ It is noteworthy that the Sudan is set hold a national referendum following the end of the six-year transitional period stipulated in the Comprehensive Peace Agreement (CPA) of January 2005. Sudan postconflict peace building seems promising so far.
} 
providing education and attempting to support local efforts to ensure the rule of law in countries in the region.

In this light, it is crucial to reach out to Islamic communities in the region and work towards creating an atmosphere of harmony and equity between Islamic and non-Islamic populations in Ethiopia, Eritrea, Tanzania and Kenya; where there have been misconceptions and disagreements on mitigation and apprehension of terror suspects.

IGAD must work towards resolving the Ethiopia-Eritrea conflict that has manifested itself in Somalia rivalries. This will ease the tension and give way for a truly conclusive counter-terrorism strategy for the region.

Stemming from the above action, the African Union and IGAD states should find a lasting solution to the Somalia problem. Somalia is indeed the epicentre of terrorist activity for obvious reasons- the resilient anarchy in the country. Perhaps a military solution is not the best way forward. There is need for a clear and decisive approach, which is directed towards creating a harmony of interests. Towards this end, a Hybrid AU-UN Peace Keeping Force is perhaps the best way forward.

There is urgent need for coordinated intelligence analysis and policy making capabilities in the region. In this vein, counter-terrorism strategies must be well connected among the countries' security machinery. This would be with the view of strengthening counterterrorism capabilities and encouraging trans-regional cooperation.

\section{References}

Afsir Karim Maj. Gen. Rtd. Counter Terrorism: The Pakistan Factor (New Delhi, Lancer International, 1991).

Cedric Bernes and Harun Hassan "The Rise and fall of Mogadishu Islamic Courts" African Programme, April 2007

Charles Onyango-Obbo “Al-Quaeda, Al-Shabaab Will Surely Rele the World” in, The East African (July 19-25, 2010).

Christopher C. Harmon Terrorism Today (London, Frank Cass, 2000)

Colliers J. “Terrorism and Africa” African Security Review 12(4), 2003

Elizabeth Chadwick Self-Determination, Terrorism and the International Humanitarian Law of Armed Conflict (The Hague, Martinus Hojnoff Publishers, 1996)

Fathali Moghaddam and Anthony Marsella (Eds) Understanding Terrorism: Psychological Roots, Consequences and Interventions (Washington DC, APA, 2004).

Gayle Rivers, The War Against the Terrorists: How to Win It (New York), Stein and Day Publishers, 1986).

Georges-Abeyie and Hass "Propaganda by Deed: Defining Terrorism" The Justice Reporter 2(3) (May-June, 1982).

ICG Africa Report No. 45, “Combining Terrorism in a Failed State”. Igor Primoratz (Ed) Terrorism: The Philosophical Issues (New York, Palagrave Macmillan, 2004).

Ihekwoaba D. Onwaudiwe "A Critical Theoretical Analysis of the Old and New Forms of Terrorism: Implications for Africa and the Third World” The International Journal of African Studies Volume 5.2 (Winter, 2006). 
Ihekwoaba D. Onwaudiwe "Explaining Terrorism in Africa" in The International Journal of African Studies Volume 5.2 (Winter, 2006).

Ihekwoaba D. Onwudiwe "Explaining Terrorism in Africa" in the International Journal of African Studies, Vol. 5.2 (Winter, 2006).

International Crisis Group Africa Report No. 116, “Can Somalia Crisis be Contained” 10 August, 2006: pp. 16-17

Jennifer Sims "Intelligence to Counter Terror: The Importance of All-Source Fusion” in Intelligence and National Security Volume 22; Feb. 2007; No. 1.

Jennifer Sims "Intelligence to Counter Terror: The Importance of All-Source Fusion" in Intelligence and National Security Vol.22, Feb, 2007(1).

Martha Glenshaw Terrorism in Africa: The International Library of Terrorism (New York, Macmillan, 1994).

Michael Knonenwetter Terrorism: A Guide to Events and Documents (Westport, Connectcticut, Greenwood Press, 2004).

Michael Krenonwetter Terrorism: A Guide to Events and Documents (Westport; Connecticut: Greenwood Press, 2004).

Paul Wilkinson (Ed) Technology and Terrorism (London, Frank Cass, 1993)

Schwartz S. The Two Faces of Terrorism: Saudi Fundamentalism and Its Role in Terrorism (New York, Anchor Books, 2003).

See report by Albert Walkers "Fourteenth Time Lacking” in BBC Focus on Africa JanMarch 2005).

Stefan Mair "Terrorism and Africa” in African Security Review Vol. 12, No. 1, 2003

Terrenie Lyons "Eritrea-Ethiopia tension fuelling Somalia’s Crisis"; December 25-31, 2006)

Tom Downey's Discussion “Al-Qaeda in Africa” in BBC Focus on Africa (July to September 2006)

UN General Assembly Resolution 49/60, Measures to Eliminate International Terrorism December 1995)

United States Institute of Peace Terrorism in the Horn of Africa (Washington DC 2004)

West D.L. "Combating Terrorism in the Horn of Africa and Yemen "BCSIA, Harvard University, Retrieved, in Oct. 10, 2005, from http://bcsia.ksg.havard.edu

White J.R. Terrorism and Homeland Security (United States: Thomson-Waldsworth, 2006

\section{Other Sources}

East African December 25-31, 2006: p. 7.

The East African “Uganda Reaches Out to Somali Militia” June 11-17, 2007, p.6

The Economist (January 4, 2003)

The East African, 22-28 Nov. 2004, p. 1.

The East African November 22-28, 2004

The Standard, Feb. 18, 2005, p. 19

Daily Nation May 21, 2006.

The East African August 7-13, 2006, p.8

The East African June 12-18, 2006, p. 19

Daily Nation “Africa News” 28, December, 2006, p. 16

The Daily Nation $10^{\text {th }}$ January 2007, p. 14. 
Daily Nation $10^{\text {th }}$ January 2007, p. 1 Daily Nation, January 10, 2007 p. 5

Daily Nation January 10, 2007. p. 14

Daily Nation January, 12 2007, p.11

The Daily Nation January 12, 2007 p.11

Daily Nation May 18, 2007; p. 19

The Daily Nation June 5 2007, p. 18.

Daily Nation March, $5^{\text {th }} 2008$

Daily Nation August 22 2009

The East African July 19-25, 2010, pp.3-9

The Global Post (January $7^{\text {th }}, 2010$ ).

Daily Nation Tuesday, March $9^{\text {th }}, 2010$

Voice of America July $5^{\text {th }} 2010$

Reuters $15^{\text {th }}$ February, 2010. 